\title{
Prevalence of nursing diagnoses in an intensive care unit
}

\author{
Prevalência de diagnósticos de enfermagem em unidade de terapia intensiva
}

Vinicia de Holanda Cabral ${ }^{1}$, Ítalo Rigoberto Cavalcante Andrade ${ }^{1}$, Elizabeth Mesquita Melo ${ }^{1}$, Tatiana de Medeiros Colletti Cavalcante ${ }^{1}$

Objective: to identify the main nursing diagnostic titles used in the care of critically ill patients hospitalized in an Intensive Care Unit, verifying the presence thereof in the diagnoses of NANDA International's Taxonomy II. Methods: descriptive and documental study, in which 69 medical records of patients aged over 18 years were consulted. Results: 22 nursing diagnostic titles were found; the most frequent was risk for infection (99.0\%), risk for skin integrity (75.0\%) and risk for aspiration (61.0\%). Most diagnoses were in the domains safety/ protection $(43.0 \%)$ and activity/rest (26.5\%). Conclusions: authors identified the main nursing diagnostic titles used in the care of critically ill patients admitted to the Intensive Care Unit and the presence thereof in the diagnoses of NANDA International's Taxonomy II.

Descriptors: Nursing Diagnosis; Nursing Process; Intensive Care Units; Critical Care.

Objetivo: identificar os principais títulos diagnósticos de enfermagem utilizados na assistência a pacientes críticos internados em Unidade de Terapia Intensiva, verificando a presença dos mesmos na taxonomia II de diagnósticos da NANDA International. Métodos: estudo descritivo e documental, no qual foram consultados 69 prontuários de pacientes com idade acima de 18 anos. Resultados: foram encontrados 22 títulos diagnósticos de enfermagem, sendo que os mais frequentes foram risco de infecção $(99,0 \%)$, risco de integridade da pele $(75,0 \%)$ e risco de aspiração (61,0\%). A maior quantidade de diagnósticos esteve presente nos domínios segurança/proteção $(43,0 \%)$ e atividade/repouso (26,5\%). Conclusões: foram identificados os principais títulos diagnósticos de enfermagem utilizados na assistência a pacientes críticos internados em Unidade de Terapia Intensiva e verificou-se a presença dos mesmos na taxonomia II de diagnósticos da NANDA International. Descritores: Diagnóstico de Enfermagem; Processos de Enfermagem; Unidades de Terapia Intensiva; Cuidados Críticos.

\footnotetext{
${ }^{1}$ Universidade de Fortaleza. Fortaleza, CE, Brazil. 


\section{Introduction}

Nursing care has undergone transformations as it has incorporated new knowledge and technological advances in its practice, with special emphasis on the use and institutionalization of the Systematization of Nursing Care in the various Brazilian health services ${ }^{(1)}$.

The implementation of the Systematization of Nursing Care is based on the guided use of the Nursing Process, which is organized in five stages: data collection (or nursing history), nursing diagnoses, nursing planning, implementation and evaluation ${ }^{(1)}$. Its use enables greater safety and credibility to nursing actions $^{(2)}$.

Systematization of Nursing Care is essential in all services in which there is nursing care; it is of paramount importance in the care of critically ill patients who are in an Intensive Care Unit, which is a place for the treatment of critically ill patients who need complex care and continuous monitoring(3).

In spite of the importance of systematization of care for critical patients and of the positive attitude of nurses facing this process ${ }^{(4-6)}$, the use thereof in the daily practice of nurses is still complex, and many difficulties are encountered in its implementation. Among these difficulties, the following can be pointed out: lack of knowledge and of motivation by the institution or during the process of educational training, and lack of material and human resources ${ }^{(4-6)}$

Having knowledge of the profile of patients admitted to an Intensive Care Unit facilitates the systematization, reduces difficulties during its accomplishment and guides nursing care ${ }^{(7-8)}$. Thus, considering the importance of its use in nursing care to critical patients, and considering the complexity of its use, this study focuses only on the phase of definition of nursing diagnoses in order to collaborate in the design of the profile of patients hospitalized in the Intensive Care Unit through the identification of the main diagnoses.
The nursing diagnosis is a clinical judgment of the individual's, family's or community's responses to actual or potential health problems ${ }^{(9)}$. The definition of nursing diagnoses is the basis for the selection of nursing interventions that allow the achievement of the results for which the nurse is responsible in the care to the client ${ }^{(10)}$.

The study of the most prevalent nursing diagnoses in critical patients will contribute to the identification of the main needs of these patients, as well as to a greater understanding of nurses and the general population about the importance of Systematization of Nursing Care, especially for critical patients. It may also guide continuing education programs for the nursing team that works with this patient profile.

Thus, this study aims to identify the main nursing diagnostic titles used in the care of critically ill patients hospitalized in the Intensive Care Unit, verifying their presence in the diagnoses of NANDA International's taxonomy II.

\section{Methods}

This is a descriptive and documentary study in which medical records hospitalized in an Intensive Care Unit of a general hospital in Fortaleza, Brazil, were consulted.

This study included data obtained from medical records of patients hospitalized at the time of data collection and who presented a record of nursing diagnoses in the first 24 hours of patient admission. Records that did not present any of the nursing records referring to the patient's date of admission to the Intensive Care Unit and those belonging to patients under 18 years old were excluded. Only one medical record was excluded because it belonged to a patient under the age of 18.

Data collection was carried out from January to May 2016. For this purpose, during the consultation to the record, a script was used to investigate charac- 
teristics such as age, gender, date of admission and reason for hospitalization in the unit studied, besides a worksheet for transcription of the titles of nursing diagnoses found. The titles found were organized between problem-focused diagnoses and risk diagnoses, present in NANDA-I's Taxonomy II ${ }^{(9)}$. Their absolute and relative frequencies were analyzed, as well as the confidence interval for the proportion found; $95.0 \%$ confidence intervals were built. However, the accuracy of the diagnostic titles found was not evaluated, since neither the defining characteristics nor the related factors for the problem-focused diagnoses were evaluated. The risk factors for the risk diagnoses were not evaluated, also.

The study complied with the formal requirements contained in the national and international regulatory standards for research involving human beings.

\section{Results}

A total of 69 records were analyzed during the data collection period, of which 38 (55.0\%) were from males and $31(45.0 \%)$ were from females. The age range varied between 19 and 88 years, with a mean age of 56.1 years and a median of 58 years; of that total, $19.0 \%$ were aged between 19 and 40 years, $24.0 \%$ between 40 and 60 years and $46.0 \%$ were aged $\geq 60$ years.

Regarding the reasons for hospitalization and associating these reasons with the main organic systems involved, it was found that $47.8 \%$ of the studied population was hospitalized in the Intensive Care Unit due to affections in the nervous system and $27.5 \%$ due to problems in the gastrointestinal system. Although pulmonary causes appeared as the main cause of hospitalization in only $10.1 \%$ of the cases, it was described as a complication associated with hospitalization in $19.4 \%$ of the other cases not initially associated with the pulmonary system. The frequencies corresponding to the respective reasons for hospitalization can be observed in Table 1 .
Table 1 - Frequency of reasons for hospitalization in the Intensive Care Unit according to the main organic systems involved $(\mathrm{n}=69)$

\begin{tabular}{lcc}
\hline Organic Systems & $\mathbf{n}(\mathbf{\%})$ & $\begin{array}{c}\text { Confidence Interval } \\
\mathbf{( 9 5 \% )}\end{array}$ \\
\hline Neurological & $33(47.8)$ & $41.81-53.84$ \\
Gastrointestinal & $19(27.5)$ & $22.16-32.91$ \\
Pulmonary & $7(10.1)$ & $6.51-13.78$ \\
Cardiology/vascular & $4(5.8)$ & $2.98-8.61$ \\
Genito-urinary & $4(5.8)$ & $2.98-8.61$ \\
Other causes ${ }^{*}$ & $2(2.9)$ & $0.88-4.92$ \\
*Exogenous intoxication and postoperative of mandibular excision
\end{tabular}

It is important to note that, in NANDA-I's taxonomy II, nursing diagnoses are organized in 13 domains. In this research, the diagnoses found can be arranged among seven domains of this classification, and this distribution can be seen in Table 2 .

Table 2 - Frequencies of the nursing diagnoses of the researched Intensive Care Unit, organized according to the domains of NANDA-I's taxonomy II $(n=514)$

\begin{tabular}{lcc}
\hline Domain & $\mathbf{n}(\%)$ & $\begin{array}{c}\text { Confidence } \\
\text { Interval (95\%) }\end{array}$ \\
\hline Domain 2 - Nutrition & $70(13.6)$ & $12.06-15.07$ \\
Domain 3 - Elimination and exchange & $30(5.8)$ & $4.78-6.84$ \\
Domain 4 - Activity/rest & $136(26.5)$ & $24.42-28.30$ \\
Domain 5 - Perception/cognition & $29(5.6)$ & $4.61-6.63$ \\
Domain 9 - Coping/stress tolerance & $10(2.0)$ & $1.33-2.54$ \\
Domain 11 - Safety/Protection & $221(43.0)$ & $40.65-45.01$ \\
Domain 12 - Comfort & $18(3.5)$ & $2.68-4.30$ \\
\hline
\end{tabular}

Thus, there was a greater predominance of the domains safety/protection (43.0\%) and activity/ rest $(26.5 \%)$, followed by the domain nutrition with 13.6\%. The domains elimination/exchange (5.8\%), perception/cognition (5.6\%), comfort (3.5\%), and coping/stress tolerance $(2.0 \%)$ appeared with percentages lower than $10.0 \%$.

The institution where the study was carried out 
provides the realization of the Systematization of Nursing Care through computerized means, in which 22 titles of pre-established nursing diagnoses are made available to nurses, all of which were found during this research.

In Table 3, these titles found are organized between. The corresponding frequency of each title is also described in Table 3.

Table 3 - Frequency of titles of nursing diagnoses identified in the Intensive Care Unit; problem-focused and risk diagnoses $(n=69)$

\begin{tabular}{|c|c|c|}
\hline Nursing Diagnoses & n (\%) & $\begin{array}{c}\text { Confidence } \\
\text { Interval }(95 \%)\end{array}$ \\
\hline \multicolumn{3}{|l|}{ Risk Diagnoses } \\
\hline Infection & $68(98.6)$ & $95.7-100$ \\
\hline Skin integrity & $52(75.4)$ & $65.2-85.5$ \\
\hline Aspiration & $42(60.9)$ & $49.4-72.4$ \\
\hline Unstable glycemia & $38(55.1)$ & $43.3-66.8$ \\
\hline Falls & $20(29.0)$ & $18.3-39.7$ \\
\hline Ineffective cerebral tissue perfusion & $17(24.6)$ & $14.5-34.8$ \\
\hline Bleeding & $13(18.8)$ & $9.6-28.1$ \\
\hline \multicolumn{3}{|l|}{ Problem-focused diagnoses } \\
\hline $\begin{array}{l}\text { Ineffective respiratory pattern/ineffective } \\
\text { airway clearance }\end{array}$ & $36(52.2)$ & $40.4-64$ \\
\hline Impaired bed mobility & $32(46.4)$ & $34.6-58.1$ \\
\hline Impaired urinary elimination & $24(34.8)$ & $23.5-46$ \\
\hline Decreased cardiac output & $22(31.9)$ & $20.9-42.9$ \\
\hline Impaired self-care & $21(30.4)$ & $19.6-41.3$ \\
\hline $\begin{array}{l}\text { Unbalanced nutrition for less than bodily } \\
\text { needs }\end{array}$ & $20(29.0)$ & $18.3-39.7$ \\
\hline Acute/chronic pain & $18(26.1)$ & $15.7-36.4$ \\
\hline Acute confusion/risk for falls & $18(26.1)$ & $15.7-36.4$ \\
\hline Hyperthermia & $14(20.3)$ & $10.8-29.8$ \\
\hline Impaired skin integrity & $12(17.4)$ & $8.4-26.3$ \\
\hline Deficient fluid volume/excessive fluid volume & $12(17.4)$ & $8.4-26.3$ \\
\hline Impaired communication & $11(15.9)$ & $7.3-24.6$ \\
\hline Anxiety & $10(14.5)$ & $6.2-22.8$ \\
\hline $\begin{array}{l}\text { Impaired mobility/impaired physical } \\
\text { mobility }\end{array}$ & $8(11.6)$ & $4.0-19.1$ \\
\hline Constipation & $6(8.7)$ & $2.0-15.3$ \\
\hline
\end{tabular}

In this sense, it can be observed that the 22 titles found can be divided into seven $(32.0 \%)$ risk diagnoses and 15 (68.0\%) problem-focused diagnoses. Thus, 514 diagnostic titles were transcribed, of which 250 (49.0\%) were classified as risk diagnoses and 264 $(51.0 \%)$ as problem-focused diagnoses, with a mean of 7.5 diagnoses per patient (ranging from 3 to 22).

The most prevalent diagnostic titles were the risk for infection (99.0\%), risk for skin integrity (75.0\%), risk for aspiration (61.0\%), risk for unstable glycemia (55.0\%), and ineffective respiratory pattern/ ineffective airway clearance (52\%), all appearing in more than half the population under investigation.

\section{Discussion}

This study had as limitations the fact that the studied population was composed of patients hospitalized at the moment of data collection in a single hospital, which does not allow the generalization of the results for other services, and the computerized selection of the diagnoses, since it limits the clinical reasoning of the nurse, reducing the action of diagnosing only to the act of choosing the most appropriate nursing diagnosis for the patient. Also, the amount of pre-established diagnoses was reduced, compared to the total diagnoses found in NANDA-I.

However, the identification of the most frequent diagnostic titles provides a better delineation of the profile of critical patients and allows that the health professionals involved in the care of these patients can obtain better interventions and results in the nursing care to critical patients.

The prevalence of males in the studied population was also found in other studies ${ }^{(10)}$; female predominance was found among the patients of other Intensive Care Units studied ${ }^{(11-13)}$, with a small difference between the percentages, showing some equality between the genders. Regarding the age group, it was found an even higher percentage of patients aged $\geq 60$ years, $68.3 \%{ }^{(14)}$.

The high frequency of neurological causes mo- 
tivating hospitalization may be associated with the fact that the hospital where the research was performed is a reference in the state of Ceará in neurosurgery and clinical neurology. Other studies indicate a higher prevalence of pulmonary (28.7\%) and cardiological (28.7\%) diseases as the main causes of hospitalization in the Intensive Care Unit, followed by diseases in the neurological (12.0\%) and gastrointestinal systems $(10.7 \%)^{(10)}$.

It is important to note that the 22 diagnostic titles found can be associated with 29 diagnoses of NANDA-I's Taxonomy II ${ }^{(9)}(11.1 \%$ of the 261 diagnoses present in the taxonomy), since the research institution has, through computerized means, the referred titles as described in table 3 , that is, in some cases, more than one title are grouped together in a same item to be selected by the nurse.

Among the diagnoses found, $49.0 \%$ were considered risk diagnoses, indicating a high concern not only with problems already installed, but also with potential problems. The mean of 7.5 diagnoses per patient was an intermediate value when compared to other similar studies that found averages equal to 19.4 ${ }^{(15)}, 8.5^{(14)}$ and $1.3^{(10)}$.

This diversity points out to the regional differences in the use of the Systematization of Nursing Care, especially in the phase of definition of diagnoses. This divergence may be associated with the way the systematization is performed and the number of diagnoses made available and/or used by nurses, since, unlike the 22 titles found in the present study, other studies showed different amounts of titles, with values varying from $13^{(12)}$ to 71 different nursing diagnoses $^{(15)}$.

Among the most frequent risk nursing diagnoses, the diagnosis of risk for infection also appears with high frequency in several studies ${ }^{(12,14-16)}$, as well as the risk for impaired skin integrity and risk for unstable glycemia, with percentages above $50.0 \%^{(14-15)}$, thus indicating the awareness and knowledge of nurses in relation to situations of risk to the patient.

Other diagnoses can also be found with high prevalence, such as the risk for constipation $(100.0 \%)^{(14)}$, risk for disuse syndrome $(86.0 \%)$ ${ }^{(15)}$, risk for aspiration $(85.7 \%)^{(12)}$ and risk for fluid imbalance $(78.0 \%)^{(15)}$.

Among the problem-focused nursing diagnoses, the diagnoses related to self-care appear in other studies to a greater extent, such as bathing/hygiene self-care deficit $(100.0 \%)^{(12,14)}$, deficit in self-care: bathing and/or hygiene $(98.1 \%)^{(16)}$, intimate hygiene self-care deficit $(93.0 \%)^{(14)}$, feeding self-care deficit $(85.7 \%)^{(12)}$.

Other diagnoses that also appeared with high percentages were interrupted family processes $(93.0 \%)^{(14)}$, impaired physical mobility $(85.7 \%)^{(12)}$, ineffective tissue perfusion $(80.0 \%)^{(12)}$, constipation $(71.4 \%)^{(12)}$, acute confusion $(71.4 \%)^{(12)}$, ineffective airway clearance $(70.0 \%)^{(15)}$, impaired social interaction(68.0\%) $)^{(15)}$, impaired oral mucous membrane $(63.0 \%)^{(15)}$.

By the analysis of these frequencies, we can see that the most prevalent diagnoses are found predominantly in the domains 4 (activity/rest) and 11 (safety/ protection) of NANDA-I ${ }^{(9)}$, fact corroborated by the literature ${ }^{(13,17)}$. In this sense, it is observed the nursing concern with patient safety and autonomy.

Regarding the use of the Systematization of Nursing Care, however, other works and initiatives are needed in order to encourage and expand its adequate use, since the real contribution of nursing to the quality of care to the critical patient in the Intensive Care Unit still appears undetermined and underesti$\operatorname{mated}^{(15)}$.

\section{Conclusion}

This study identified the main nursing diagnostic titles used in the care of critically ill patients admitted to the intensive care unit and verified the presence of these titles in the diagnoses of NANDA-I's taxonomy II. Thus, 22 nursing diagnostic titles were found in similar proportions when organized between risk diagnoses and problem-focused diagnoses. These titles, 
made available to the nurses by computerized means, were all listed among the research findings.

However, there were some differences between the titles made available by the institution studied and NANDA-I diagnoses, such as the grouping of diagnoses in a unitary option to be selected by the nurse during the Systematization of Nursing Care.

\section{Collaborations}

Cabral VH and Andrade IRC contributed to the project design, collection, organization, analysis and interpretation of the data, writing of the article and final approval of the version to be published. Melo EM and Cavalcante TMC contributed in the writing of the article and relevant critical review of the content of the article.

\section{References}

1. Conselho Federal de Enfermagem (BR). Resolução no. 358, de 2009. Dispõe sobre a Sistematização da Assistência de Enfermagem e a implementação do Processo de Enfermagem em ambientes, públicos ou privados, em que ocorre o cuidado profissional de Enfermagem, e dá outras providências. Brasília: COFEN; 2009.

2. Tannure MC, Pinheiro AM. SAE: Sistematização da Assistência de Enfermagem: Guia Prático. Rio de Janeiro: Guanabara Koogan; 2014.

3. Schwonke CRGB, Lunardi Filho WD, Lunardi VL, Santos SSC, Barlém ELD. Perspectivas filosóficas do uso da tecnologia no cuidado de enfermagem em terapia intensiva. Rev Bras Enferm. 2011; 64(1):189-92.

4. Silva VS, Barbosa Filho ES, Queiroz SMB, Abreu RNDC. Utilização do processo de enfermagem e as dificuldades encontradas por enfermeiros. Cogitare Enferm. 2013; 18(2):351-7.
5. Hagos F, Alemseged F, Balcha F, Berhe S, Aregay A. Application of nursing process and its affecting factors among nurses working in Mekelle Zone Hospitals, Northern Ethiopia [Internet]. 2014 [cited 2016 Feb 20]. Available from: http://www. hindawi.com/journals/nrp/2014/675212/

6. Santos MGPS, Medeiros MMR, Gomes FQC, Enders BC. Percepção de enfermeiros sobre o processo de enfermagem: uma integração de estudos qualitativos. Rev Rene. 2012; 13(3):712-23.

7. Pivoto FL, Lunardi Filho WD, Santos SSC, Almeida MA, Silveira RS. Nursing diagnoses in patients in the postoperative period of cardiac surgery. Acta Paul Enferm. 2010; 23(5):665-70.

8. Paans W, Roos MB, Cees N, Schans PV, Sermeus $\mathrm{W}$. What factors influence the prevalence and accuracy of nursing diagnoses documentation in clinical practice? A systematic literature review. J Clin Nurs. 2011; (20):2386-403.

9. North American Nursing Diagnosis Association/ NANDA-I. Diagnósticos de Enfermagem da NANDA: definições e classificação 2015-2017. Tradução de Regina Machado Garcez. Porto Alegre: Artmed; 2015.

10. Paganin A, Menegat P, Klafke T, Lazarotto A, Fachinelli TS, Chaves IC, et al. Implantação do diagnóstico de enfermagem em unidade de terapia intensiva: uma análise periódica. Rev Gaúcha Enferm. 2010; 31(2):307-13.

11. Chianca TCM, Lima APS, Salgado PO. Nursing diagnoses identified in inpatients of an adult intensive care unit. Rev Esc Enferm USP. 2012; 46(5):1102-8.

12. Gomes RKG, Lopes MVO. Diagnósticos de enfermería en individuos ingresad os en unidad de cuidados intensivos. Av Enferm. 2013; 31(2):1121.

13. Melo EM, Albuquerque MP, Aragão RM. Diagnósticos de Enfermagem Prevalentes na Unidade de Terapia Intensiva de um Hospital Público. Rev Enferm UFPE On line [Internet]. 2012; [citado 2016 fev 20];6(6):1361-8. Disponível em: http://www. revista.ufpe.br/revistaenfermagem/index.php/ revista/article/viewFile/2514/pdf_1212 
14. Salgado PO, Chianca TCM. Identification and mapping of the nursing diagnoses and actions in an Intensive Care Unit. Rev Latino-Am Enfermagem. 2011; 19(4):9238-35.

15. Castellan C, Sluga S, Spina E, Sanson G. Nursing diagnoses, outcomes and interventions as measures of patient complexity and nursing care requirement in Intensive Care Unit. J Adv Nurs. 2016; 72(6):1273-86.
16. Lucena AF, Gutiérrez MGR, Echer IC, Barros ALBL. Nursing interventions in the clinical practice of an intensive care unit. Rev Latino-Am Enfermagem. 2010; 18(5):873-80.

17. Yücel SC, Eser I, Güler EK, Khorshid L. Nursing diagnoses in patients having mechanical ventilation support in a respiratory intensive care unit in Turkey. Int J Nurs Pract. 2011; 17(5):502-8. 